\title{
Porcupine gnaw marks on a Late Pliocene bone from the Upper Siwaliks exposed near Village Khetpurali (Haryana, India)
}

\author{
JAGJEET KAUR ${ }^{1}$, RAJEEV PATNAIK ${ }^{1}$, BAHADUR SINGH ${ }^{2}$ and KEWAL KRISHAN ${ }^{2}$ \\ ${ }^{1}$ Department of Geology, Panjab University, Sector 14, 160014 Chandigarh, India \\ ${ }^{2}$ Department of Anthropology, Panjab University, Sector 14, 160014 Chandigarh, India
}

Manuscript received on November 14, 2017; accepted for publication on July 19, 2018

\begin{abstract}
How to cite: KAUR J, PATNAIK R, SINGH B AND KRISHAN K. 2019. Porcupine gnaw marks on a Late Pliocene bone from the Upper Siwaliks exposed near Village Khetpurali (Haryana, India). An Acad Bras Cienc 91: e20170910. DOI 10.1590/0001-3765201920170910.

Abstract:Bone accumulation by porcupines at archaeological sites is well known. However, in paleontological sites such a taphonomical occurrence is rather rare. We here report porcupine (Hystrix sp.) gnaw marks on an unidentified bone fragment, dated to $\sim 2.6 \mathrm{Ma}$ from the Upper Siwalik deposits exposed near Khetpurali (Haryana), India. The present gnaw marks are very distinct and are characterized by visible edges and grooves making clear broad and shallow furrows. The present find adds to our knowledge of Siwalik vertebrate taphonomy where most of the accumulations reported earlier were either fluvial or made by carnivores.
\end{abstract}

Key words: porcupine, gnaw marks, Upper Siwalik, taphonomy.

\section{INTRODUCTION}

Some of the first taphonomical studies in the world were carried out on Siwalik vertebrate fossils wherein work was carried out on both experimental and field methods to understand the accumulation of vertebrate fossils. The taphonomic studies in the Siwaliks have so far been concentrated mostly on large mammals vis-à-vis their environment and mode of deposition (Gaur and Chopra 1984, Badgley 1986, Barry et al. 1995, Badgley and Behrensmeyer 1995, Behrensmeyer and Barry 2005, Dennell et al. 2005). The Siwalik exhibits fossil accumulations both by natural (fluvial) and biological (mostly carnivores) agents. Scatological

Correspondence to: Rajeev Patnaik

E-mail: rajeevpatnaik@gmail.com

ORCid: http://orcid.org/0000-0003-2542-7898 accumulations have also been reported (Patnaik 1995). A large number of fossil bones have been recovered since the early $19^{\text {th }}$ century but there are very few findings of biogenically modified fossilised bones till date. A recent discovery of alleged cut marks on long bones recovered from the Upper Siwaliks exposed at Masol near Chandigarh (Malassé et al. 2016) has generated a lot of interest on whether early humans were responsible for these modified bones or the cut marks are made by other processes. While looking for ancient bones modified by early carnivores/scavengers in the Upper Siwaliks near Chandigarh, we have come across a fragment of a long bone from Khetpurali (Figure 1, $\sim 50 \mathrm{~km}$ east of Masol) showing gnawing marks (Figures 2 and 3 ) possibly made by porcupines. Although, porcupines (Hystrix sp.) are known for transporting, accumulating and gnawing 


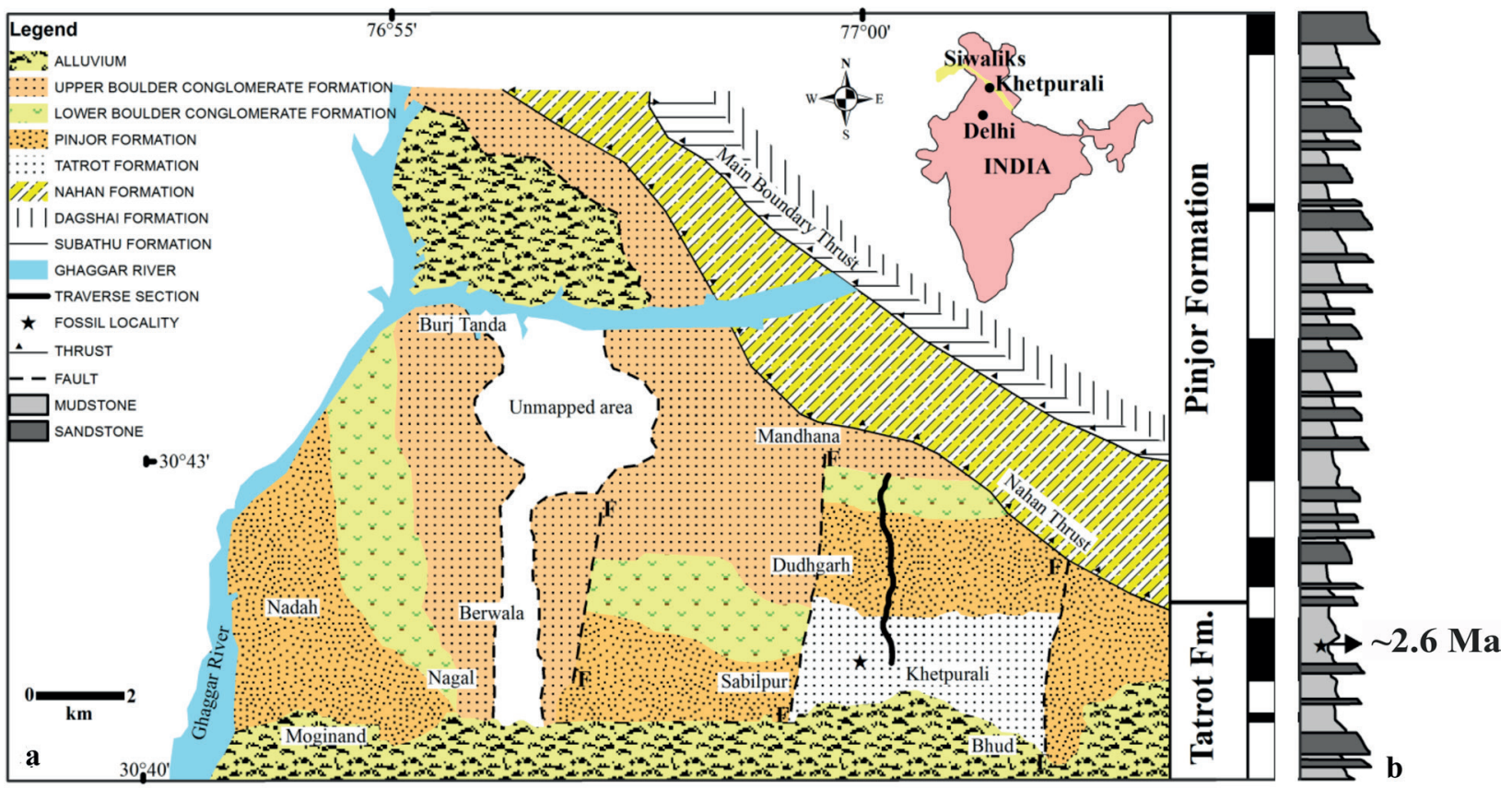

Figure 1 - a, Geology and stratigraphy of the Khetpurali section, India, showing the fossil site. $\mathbf{b}$, The location of the fossil site and its approximate age in correlation with the magnetostratigraphically dated Khetpurali Nala section (data from Tandon et al. 1984).

the skeletal material in the archaeological record, report of gnawing by porcupines in paleontological accumulations of Miocene-Pliocene times are rather rare (international examples are cited below). In fact porcupine act as a major taphonomic agent and have been found to disturb sites resulting in the mixing of archaeological material (Lenoble et al. 2008, Więckowski et al. 2013).

The family Hystricidae most probably originated in SE Asia (Sen and Purabrishemi 2010) and appears in the Siwaliks of the Indian Subcontinent in the Middle Miocene represented by Sivacanthion complicates (Colbert 1935, Montoya 1993, Van Weers 2005). In the Middle Siwalik Hystrix sivalensis at $8.0 \mathrm{Ma}$ (Lydekker 1878, Black 1972, Barry et al. 2002) followed by the appearance of Hystrix cf. H. leucurus in the Upper Siwaliks (Black 1972). Today, Hystrix indica (the Indian porcupine) is fairly widespread and is found in China, Southeast Asia, Indonesia, IndoPakistan, and the Mediterranean region (Hlusko 2007). Though the occurrence of Hystrix sp. from the Siwaliks has been dated to the Miocene times, gnawing marks on fossil bones made by them have never been reported till date from South Asia. The present paper deals with an isolated mammalian limb bone showing possible evidence of porcupine gnawing. It was recovered from a paleomagnetically dated $\sim 2.6$ Ma Khetpurali section (Tandon et al. 1984). Here, the gnawing marks are described, compared and discussed in the light of taphonomic accumulation by Siwalik mammals.

\section{MATERIALS AND METHODS}

The long bone fragment $(\mathrm{KP} / \mathrm{KK} / \mathrm{BS} / 129)$ has a smooth surface, a semicircular cross section and a filled marrow cavity. It was collected by one of us (BS) from the surface of the outcrop belonging to the Tatrot Formation exposed near Khetpurali village $\left(30^{\circ} 41^{\prime} 32^{\prime \prime} \mathrm{N}, 76^{\circ} 59^{\prime} 37.4^{\prime \prime} \mathrm{E}\right)$ (Figure 1a) located about $40 \mathrm{~km}$ east of Chandigarh. Lithologically, this fossiliferous horizon consists of alternating grey to brownish grey sandstones and variegated mudstones with thickness varying from 


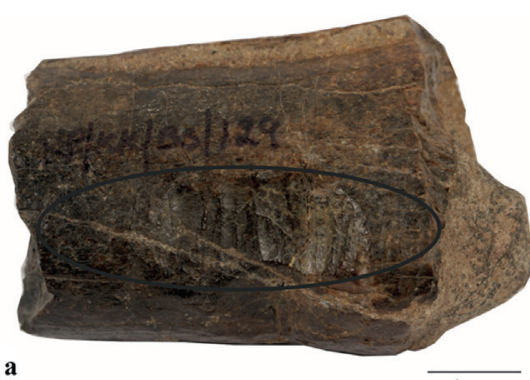

a

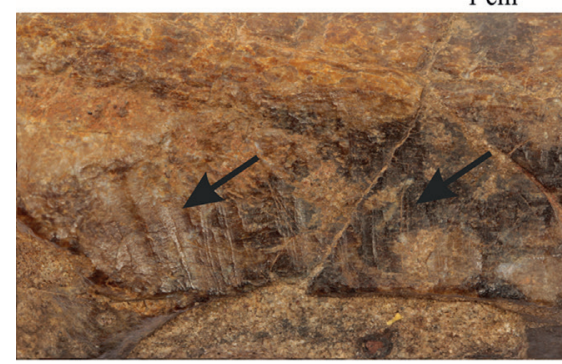

d
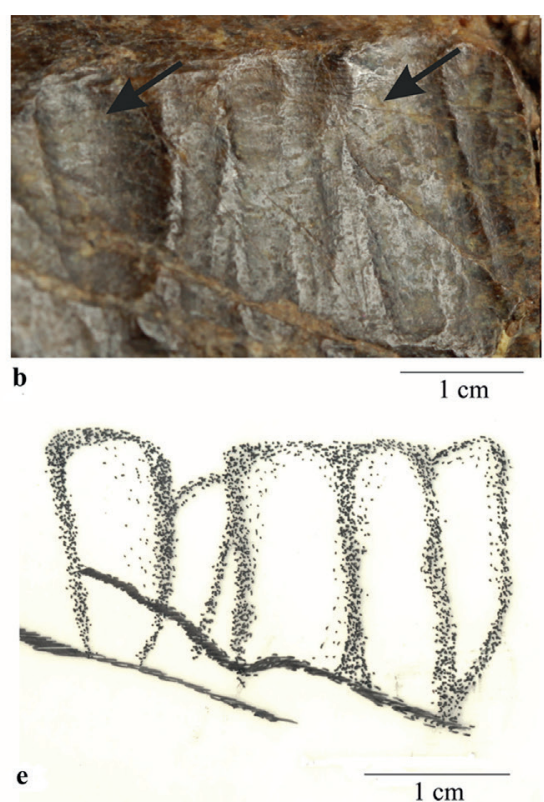

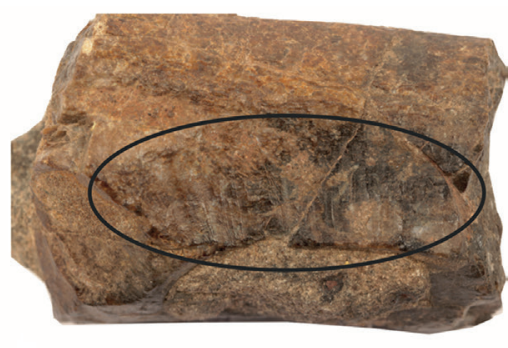

c

$1 \mathrm{~cm}$

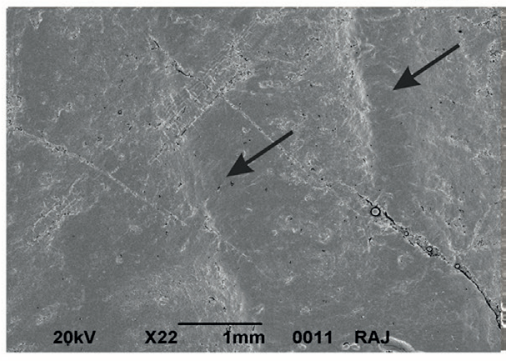

f

Figure 2 - Hystrix sp. gnawed bone (KP/KK/BS/129); a, gnawed area; b, edges and grooves made by the porcupine incisors; c, gnawed area; $\mathbf{d}$, mineralization on the gnawed area shown by arrow; e, stippled line diagram showing gnawing marks; $\mathbf{f}$, SEM image of the gnawing marks shown by arrow.
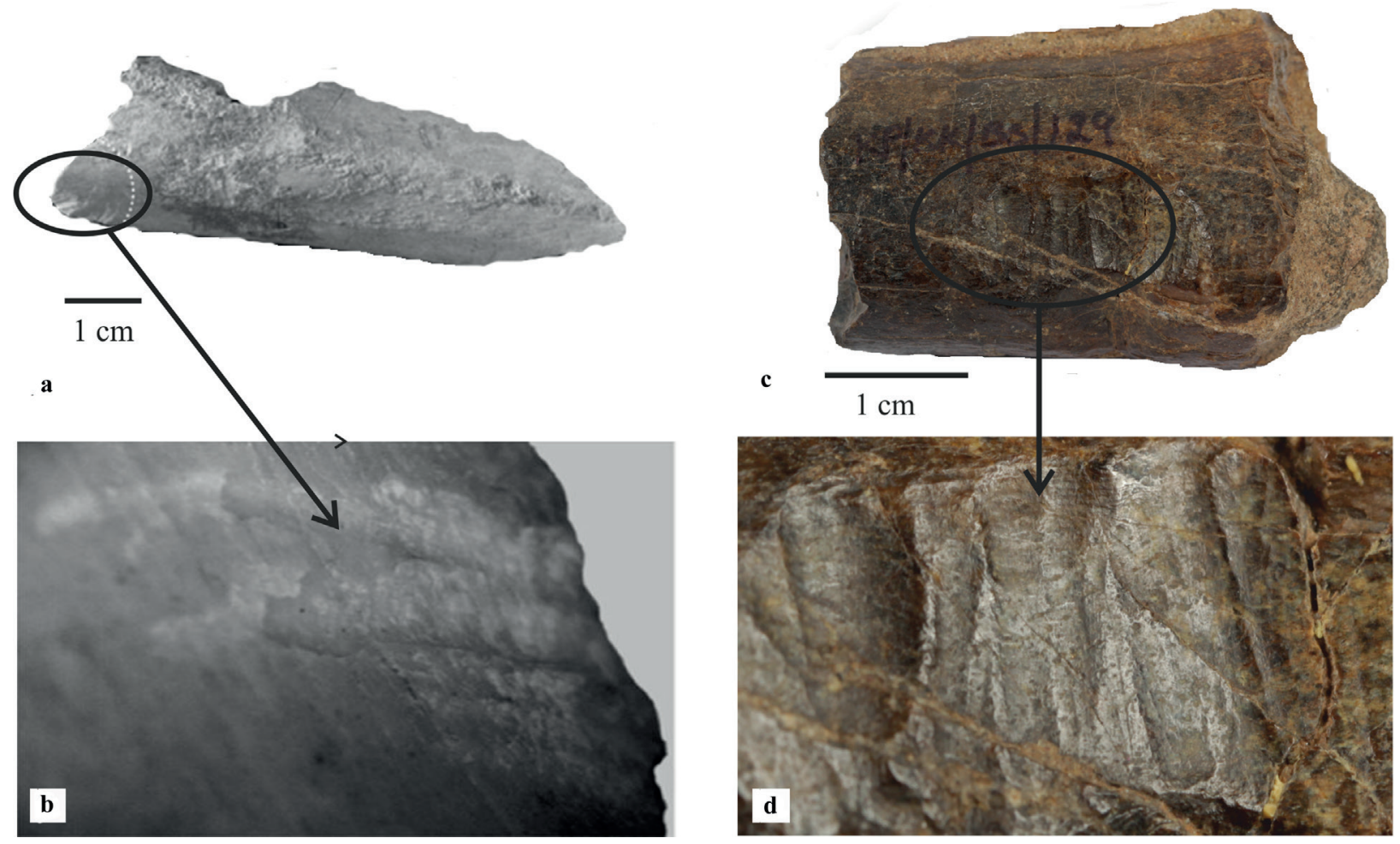

Figure 3 - a and $\mathbf{b}$ show the gnawed femur shaft collected from the Porcupine den (modified from Więckowski et al. 2013); $\mathbf{c}$ and d show the gnawing on the fossil bone fragment $(\mathrm{KP} / \mathrm{KK} / \mathrm{BS} / 129)$ collected from Siwaliks. Note the similarity between the gnaw marks of the two bones. 
1 to $5 \mathrm{~m}$. The section was measured and correlated with the paleomagnetically dated Khetpurali Nala section (Figure 1b). The fragmentary fossil bone is well preserved and is about $5.5 \mathrm{~cm}$ long and $3.5 \mathrm{~cm}$ in diameter (Figure 2a). In order to closely observe and examine the marks on the fossil bone, it was studied under a light microscope Leica S8APO (Figure 2b, $c$ and d). Figure 2e shows a line drawing of the gnawing marks. A polyester replica was prepared and the marks were scanned under the Scanning Electron Microscope- JSM 6490 housed at the Department of Geology, Panjab University, Chandigarh. Multiple grooves measuring between 2 to $5 \mathrm{~mm}$ in width and 10 to $12 \mathrm{~mm}$ in length are clearly visible (Figure 2f).

\section{RESULTS AND DISCUSSION}

The fossil clearly displays the intensity of porcupine (Hystrix sp.) gnawing. The gnawing marks are in one particular direction (Figure $2 \mathrm{~b}$ ) indicating that the porcupine was holding the bone while gnawing it for a considerable period of time. The marks have evidently visible ridges and grooves, making clearly distinguishable furrows. Ridges are straight and sharp whereas the grooves are smooth and flat. The grooves are not of uniform thickness and most likely the same area was gnawed multiple times. The gnaw marks were made prior to the burial of the bone, as the bone underwent mineralization along the fractures which overlap the gnaw marks, so the mineralization is subsequent (Figure 2d). This is also evident from the colour of the gnaw marks (damaged area) and bone as both are of the same colour (Więckowski et al. 2013). The gnaw marks on the fossil bone very clearly resemble with those made on the bones found in the recent porcupine dens (Figure 3). Though porcupines eat bark, roots, tubers, rhizomes, bulbs, fallen fruits, sometimes insects and small vertebrates, they frequently gnaw bones (Plug and Keyser 1994). The main purpose of porcupine gnawing is either incisor sharpening (Brain 1980, Lyman 1994) or nutrient intake (Swanson 1998, Thornton and Fee 2001) preferably from the dryer and weathered bones (Lyman 1994) but sometimes they also devour fresh bones (Pokines 2014). Drier and weathered bones are preferred because they are easy to gnaw (Lyman 1994). Majority of this gnawing behaviour is dietary in nature (for nutrient intake) and also to maintain the length of their ever-growing chisel-like incisors (Roze 2009). Porcupines have broad upper and lower incisors and leave broader, flatter (and deeper) gnaw marks upon bone than smaller rodents (Pokines 2014). Maguire et al. (1980) defined the gnaw marks of porcupines as "broad contiguous shallow scrape marks" and therefore they can be unmistakeably distinguished from all other marks like those made by carnivores, other animals or marks that result from butchering by humans, natural scratches or those made by tampering. Young carnivores tend to produce irregular grooves and striations while older carnivores produce punctate depressions and crenulated edges (Kibii 2009).

The oldest record of such behaviour by porcupines comes from the Upper Miocene locality of Crevillente 2 Province of Alicante, Spain (Montoya 1990). Other reports are from the Late Pliocene site of Ahl al Oughlam near Casablanca, Morocco, dated to $2.5 \mathrm{Ma}$ (Geraads 2006), Haasgat cave (Lower Pleistocene) in Witwatersrand Spruit (Plug and Keyser 1994), Drimolen (Gauteng Province, South Africa), dated 1.5-2 Ma (Backwell and d'Ericco 2008), Middle Pleistocene fossil caves in North Atlantic Morocco (Daujeard et al. 2012), Bailong Cave Site (Middle Pleistocene),Yunxi, Hubei (Xian-zhu et al. 2008), Za Hájovnou Cave (Middle Pleistocene) in Czech Republic (Sabol 2014) and other archaeological sites (Mason et al. 1958, Díez et al.1999, Pokines and Peterhans 2007, O'Regan et al. 2011, Więckowski et al. 2013) (Table I). This is perhaps the first evidence indicating 
TABLE I

Some examples of open air fossil and cave sites with preserved porcupine gnawed bones.

\begin{tabular}{|c|c|c|c|c|c|c|}
\hline $\begin{array}{l}\text { S. } \\
\text { No. }\end{array}$ & $\begin{array}{l}\text { Specimen type/ } \\
\text { species }\end{array}$ & Context & Site & Age & Country & Reference \\
\hline 1 & $\begin{array}{l}\text { Unidentified bone } \\
\text { fragments }\end{array}$ & Fossil Site & $\begin{array}{c}\text { Crevillente } 2 \text { Province of } \\
\text { Alicante }\end{array}$ & Upper Miocene & Spain & $\begin{array}{l}\text { Montoya } \\
(1990)\end{array}$ \\
\hline 2 & $\begin{array}{l}\text { Unidentified bone } \\
\text { fragments }\end{array}$ & Cave deposit & $\begin{array}{l}\text { Ahl al Oughlam near } \\
\text { Casablanca }\end{array}$ & Late Pliocene & Morocco & $\begin{array}{l}\text { Geraads } \\
(2006)\end{array}$ \\
\hline 3 & $\begin{array}{l}\text { Unidentified Bone } \\
\text { fragment }\end{array}$ & Fossil site & $\begin{array}{c}\text { Khetpurali village, East of } \\
\text { Chandigarh }\end{array}$ & Late Pliocene & India & Present work \\
\hline 4 & $\begin{array}{l}\text { Unidentified bone } \\
\text { fragments }\end{array}$ & Cave deposit & $\begin{array}{c}\text { Haasgat cave in } \\
\text { Witwatersrand Spruit }\end{array}$ & $\begin{array}{c}\text { Lower } \\
\text { Pleistocene }\end{array}$ & $\begin{array}{l}\text { South } \\
\text { Africa }\end{array}$ & $\begin{array}{c}\text { Plug and } \\
\text { Keyser } 1994\end{array}$ \\
\hline 5 & Bone tools & Cave deposit & $\begin{array}{l}\text { Gauteng Province, } \\
\text { Drimolen }\end{array}$ & $\begin{array}{c}\text { Lower } \\
\text { Pleistocene }\end{array}$ & $\begin{array}{l}\text { South } \\
\text { Africa }\end{array}$ & $\begin{array}{c}\text { Backwell } \\
\text { and d'Ericco } \\
(2008)\end{array}$ \\
\hline 6 & $\begin{array}{l}\text { Ceratotherium, } \\
\text { Bovidae, and } \\
\text { unidentified bones }\end{array}$ & Cave deposit & $\begin{array}{c}\text { Fossil caves, North Atlantic } \\
\text { (Grotte à Hominidés - GH - } \\
\text { and Grotte des Rhinocéros } \\
\text { - GDR - at Thomas I and } \\
\text { Oulad Hamida } 1 \text { quarries, } \\
\text { Casablanca) }\end{array}$ & $\begin{array}{c}\text { Middle } \\
\text { Pleistocene }\end{array}$ & Morocco & $\begin{array}{l}\text { Daujeard et } \\
\text { al. (2012) }\end{array}$ \\
\hline 7 & $\begin{array}{l}\text { Unidentified bone } \\
\text { fragments }\end{array}$ & Cave deposit & $\begin{array}{c}\text { Bailong Cave Site, Yunxi, } \\
\text { Hubei }\end{array}$ & $\begin{array}{c}\text { Middle } \\
\text { Pleistocene }\end{array}$ & China & $\begin{array}{l}\text { Xian-zhu et } \\
\text { al. (2008) }\end{array}$ \\
\hline 8 & $\begin{array}{l}\text { Right tibia of } \\
\text { Ursus deningeri }\end{array}$ & Cave deposit & $\begin{array}{c}\text { Za Hájovnou Cave, } \\
\text { Moravia }\end{array}$ & $\begin{array}{c}\text { Middle } \\
\text { Pleistocene }\end{array}$ & $\begin{array}{l}\text { The Czech } \\
\text { Republic }\end{array}$ & Sabol (2014) \\
\hline 9 & $\begin{array}{l}\text { Antlers or horn } \\
\text { fragments }\end{array}$ & Cave deposit & $\begin{array}{c}\text { Aurora Stratum, Gran } \\
\text { Dolina, Sierra de Atapuerca }\end{array}$ & $\begin{array}{c}\text { Lower } \\
\text { Palaeolithic }\end{array}$ & Spain & $\begin{array}{l}\text { Díez et al. } \\
\text { (1999) }\end{array}$ \\
\hline 10 & $\begin{array}{l}\text { Carnivore teeth, } \\
\text { Equid, Bovid } \\
\text { and Suid cranial } \\
\text { fragments }\end{array}$ & Cave deposit & $\begin{array}{c}\text { Kalakbank, Central } \\
\text { Transvaal }\end{array}$ & $\begin{array}{l}\text { Middle stone } \\
\text { age }\end{array}$ & $\begin{array}{l}\text { South } \\
\text { Africa }\end{array}$ & $\begin{array}{l}\text { Mason et al. } \\
\quad(1958)\end{array}$ \\
\hline 11 & $\begin{array}{l}\text { Bone shaft } \\
\text { fragments, Femur, } \\
\text { glenoid fragment }\end{array}$ & Cave deposit & $\begin{array}{c}\text { Post-Member } 6 \text { Infill at } \\
\text { Sterkfonte }\end{array}$ & $\begin{array}{l}\text { Middle stone } \\
\text { age }\end{array}$ & $\begin{array}{l}\text { South } \\
\text { Africa }\end{array}$ & $\begin{array}{l}\text { O’Regan et } \\
\text { al. (2011) }\end{array}$ \\
\hline 12 & $\begin{array}{l}\text { Medium mammal } \\
\text { shaft, Femur, } \\
\text { Calcaneum }\end{array}$ & Cave deposit & Tel Zahara & Roman deposits & Israel & $\begin{array}{l}\text { Więckowski } \\
\text { et al. (2013) }\end{array}$ \\
\hline 13 & $\begin{array}{l}\text { Unidentified bone } \\
\text { fragment }\end{array}$ & Cave deposit & $\begin{array}{c}\text { Masai Mara National } \\
\text { Reserve }\end{array}$ & Recent & Kenya & $\begin{array}{c}\text { Pokines and } \\
\text { Peterhans } \\
(2007)\end{array}$ \\
\hline
\end{tabular}


gnawing behaviour by porcupines (Hystrix) in the Siwalik faunal accumulation.

\section{CONCLUSIONS}

Porcupines (Hystrix sp.) are known for gnawing bones for incisor sharpening and nutrient intake. They leave characteristic gnaw marks on the bones. We here, for the first time, report porcupine gnaw marks from the Siwaliks of the Late Pliocene age. This find adds another aspect of taphonomic accumulations in the Siwalik Hills, which earlier were primarily regarded as either fluvial accumulated or thought to be made by carnivores. This find also indicates that intensive and focussed field surveys are the need of the day to make such interesting discoveries in future.

\section{ACKNOWLEDGMENTS}

JK is thankful to Department of Science and Technology (INSPIRE) Fellowship (No: IF 150266) for financial support. RP is supported by Ministry of Earth Science project (MoES/P.O. (Geoscience)/46/2015). BS and KK are supported by a PURSE GRANT and the Center for Advanced Study (CAS) awarded to the Department of Anthropology, Panjab University, Chandigarh, India. We would like to thank the two reviewers for their constructive comments.

\section{REFERENCES}

BACKWELL L AND D'ERRICO F. 2008. Early hominid bone tools from Drimolen, South Africa. J Archaeol Sci 35: 2880-2894.

BADGLEY C. 1986. Taphonomy of mammalian fossil remains from Siwalik rocks of Pakistan. Paleobiology 12: 119-142.

BADGLEY C AND BEHRENSMEYER AK. 1995. Preservational, paleoecological and evolutionary patterns in the Paleogene of Wyoming-Montana and the Neogene of Pakistan. Palaeogeogr Palaeoclimatol Palaeoecol 115: 319-340.

BARRY JC, MORGAN ME, FLYNN LJ, PILBEAM D, BEHRENSMEYER AK, RAZA SM, KHAN IA, BADGLEY C, HICKS J AND KELLEY J. 2002. Faunal and environmental change in the late Miocene Siwaliks of northern Pakistan. Paleobiology 28: 1-71.

BARRY JC, MORGAN ME, FLYNN LJ, PILBEAM D, JACOBS LL, LINDSAY EH, RAZA SM AND SOLOUNIAS N. 1995. Patterns of faunal turnover and diversity in the Neogene Siwaliks of northern Pakistan. Palaeogeogr Palaeoclimatol Palaeoecol 115: 209-226.

BEHRENSMEYER AK AND BARRY JC. 2005. Biostratigraphic surveys in the Siwaliks of Pakistan: A method for standardized surface sampling of the vertebrate fossil record. Palaeontol Electron 8: 1-24.

BLACK CC. 1972. Review of fossil rodents from the Neogene Siwalik beds of India and Pakistan. Palaeontology 15: 238266.

BRAIN CK. 1980. Some criteria for the recognition of bone collecting agencies in African caves. In: Behrensmeyer AK and Hill AP (Eds), Fossils in the making: Vertebrate taphonomy and paleoecology. University of Chicago Press, Chicago, p. 107-130.

COLBERT EH. 1935. Siwalik mammals in the American Museum of Natural History. T Am Philol Assoc 26: 1-401.

DAUJEARD C, GERAADS D, GALLOTTI R, MOHIB A AND RAYNAL JP. 2012. Carcass acquisition and consumption by carnivores and hominins in Middle Pleistocene sites of Casablanca (Morocco). J Taphonomy 10: 349-372.

DENNELL RW, COARD R, BEECH M, ANWAR M AND TURNER A. 2005. Locality 642, an Upper Siwalik (Pinjor Stage) fossil accumulation in the Pabbi Hills, Pakistan. J Palaeontol Soc India 50: 83-92.

DÍEZ JC, JALVO YF, ROSELL J AND CÁCERES I. 1999. Zooarchaeology and taphonomy of Aurora Stratum (Gran Dolina, Sierra de Atapuerca, Spain). J Hum Evol 37: 623652.

GAUR R AND CHOPRA SRK. 1984. Taphonomy, fauna, environment and ecology of Upper Sivaliks (PlioPleistocene) near Chandigarh, India. Nature 308: 353-355.

GERAADS D. 2006. The late Pliocene locality of Ah1 a1 Oughlam, Morocco: Vertebrate fauna and interpretation. T Roy Soc S Af 61(2): 97-101.

HLUSKO LJ. 2007. Earliest evidence for Atherurus and Xenohystrix (Hystricidae, Rodentia) in Africa, from the late Miocene site of Lemudong'o, Kenya. Kirtlandia 56: 86-91.

KIBII JM. 2009. Taphonomic Aspects of African porcupines (Hystrix cristata) in the Kenyan Highlands. J Taphonomy 7: 21-27.

LENOBLE A, ZEITOUN V, LAUDET F, SEVEAU A AND DOY ASA T. 2008. Natural processes involved in the formation of Pleistocene bone assemblages in continental South-east Asian caves: the case of the Cave of the Monk (Chiang Dao Wildlife Sanctuary, Thailand). In: Pautreau JP, Coupey AS, Zeitoun V and Rambault E (Eds), 
Archaeology in Southeast Asia: From Homo erectus to the living traditions. Chiang Mai, EurASEAA, p. 41-50.

LYDEKKER R. 1878. Notices of Siwalik mammals. Rec Geol Surv India 11: 64-104.

LYMAN RL. 1994. Vertebrate taphonomy. Cambridge Manuals in Archaeology, Cambridge University Press, Cambridge.

MAGUIRE JM, PEMBERTON D AND COLLETT MH. 1980. The Makapansgat limeworks grey breccia: Hominids, hyaenas, hystricids or hillwash? Palaeontol Afr 23: 75-98.

MALASSÉ AD ET AL. 2016. Intentional cut marks on bovid from the Quranwala zone, 2.6 Ma, Siwalik Frontal Range, northwestern India. C R Palevol 15: 317-339.

MASON RJ, DART RA AND KITCHING JW. 1958. Bone tools at the Kalkbank Middle Stone Age site and the Makapansgat australopithecine locality, central Transvaal. Part 1. The Kalkbank site. S Afr Archaeol Bull 13(51): 85-116.

MONTOYA P. 1990. Primeros datos sobre la tafonomia de Crevillente-2. Reunion Tafonomia Fosilizacion. Madrid 1990: 237-244.

MONTOYA P. 1993. The porcupine Hystrix suevica Schlosser, 1884 from the lower Turolian of Crevillente 2 (Spain). Scripta Geol 103: 135-149.

O'REGAN HJ, KUMAN K AND CLARKE RJ. 2011. The Likely Accumulators of Bones: Five Cape Porcupine Den Assemblages and the Role of Porcupines in the Post-Member 6 Infill at Sterkfontein, South Africa. J Taphonomy 9: 69-87.

PATNAIK R. 1995. Micromammal-based palaeoenvironment of the Upper Siwaliks exposed near village Saketi, Himachal Pradesh. J Geol Soc India 46: 429-437.

PLUG I AND KEYSER AW. 1994. Haasgat Cave, a Pleistocene site in the central Transvaal: geomorphological, faunal and taphonomic considerations. Ann Transv Mus 36(9): 139145.

POKINES JT. 2014. Faunal Dispersal, Reconcentration, and Gnawing Damage to Bone in Terrestrial Environments. In: Pokines JT and Symes SA (Eds), Manual of Forensic Taphonomy. CRC Press, Boca Raton, p. 201-248.
POKINES JT AND PETERHANS JCK. 2007. Spotted hyena (Crocuta crocuta) den use and taphonomy in the Masai Mara National Reserve, Kenya. J Archaeol Sci 34: 19141931.

ROZE U. 2009. The North American Porcupine. $2^{\text {nd }}$ ed., Cornell University Press, Ithaca, New York.

SABOL M. 2014. Basic population and taphonomic analysis of bear assemblages from Za Hájovnou Cave (Moravia, Czech Republic): a fossil record from 1987-2007. Acta Musei Nationalis Pragae Ser B Historia Naturalis 70(1-2): 71-90.

SEN S AND PURABRISHEMI Z. 2010. First porcupine fossils (Mammalia, Rodentia) from the late Miocene of NW Iran, with notes on late Miocene-Pliocene dispersal of porcupines. Palaontol Z 84: 239-248.

SWANSON D. 1998. Animals eat the weirdest things. Henry Holt and Company Inc, New York.

TANDON SK, KUMAR R, KOYAMA M AND NIITSUMA N. 1984. Magnetic polarity stratigraphy of the Upper Siwalik Subgroup, east of Chandigarh, Punjab SubHimalya, India. J Geol Soc India 25: 45-55.

THORNTON M AND FEE J. 2001. Rodent gnawing as a taphonomic agent: implications for archaeology. In: Gerlach SC and Murray MS (Eds), People and Wildlife in Northern America: Essays in Honor of R. Dale Guthrie. Oxford: BAR International Series 944, p. 300-306.

VAN WEERS DJ. 2005. A taxonomic revision of the Pleistocene Hystrix (Hystricidae, Rodentia) from Eurasia with notes on the evolution of the family. Contri Zoology 74: 301-312.

WIĘCKOWSKI W, COHEN S, MIENIS HK AND HORWITZ LK. 2013. The excavation and analysis of porcupine dens and burrowing on ancient and recent faunal and human remains at Tel Zahara (Israel). Bioarchaeol Near East 7: $3-20$.

XIAN-ZHU WU, YU-JIE LI, SHUWEN PEI AND XIU-JIE WU. 2008. Surface marks on fossil bonesat in Bailong cave site, Yunxi, Hubei. Quat Sci 28: 1023-1033. 